\title{
DISKRIMINASI PENEGAKAN HUKUM DALAM PENANGANAN PENCURIAN ARUS LISTRIK DI DISTRIK DILI
}

\author{
Oleh : \\ Nuno Saldanha Da Silva Fatima', Karolus Kopong Medan², \\ Saryono Yohanes ${ }^{3}$
}

\begin{abstract}
Law enforcement discrimination in handling the theft of electric flow in Dili District of Timor Leste, about the treatment to fellow citizes (discrimination) because the people's welfare must be the highest law in a country "salus publika supreme lex". This research is an empirical yuridical law research. This is descriptive research by using primary data and secondary data. The result of this research indicate that every service given by the government through electricidade de Timor Leste (EDTL) as electrical energy distributor starting from the generation of transmission and distribution of electrical energy which become the source of supply to all society that widespread in Dili District of East Timor. In fact, deviates from the mandate of constitution which exist for the welfare of people. The deviations that occur are followed up by unfair law action toward the various level/group that exist in the society as the costumer. Injustice in handling is basically due to the interference of power both economic or political.
\end{abstract}

Keywords: Discrimination, Law Enforcement, Electricity Theft

\begin{abstract}
Abstrak
Diskriminasi Penegakan Hukum Dalam Penanganan PencurianAliran Listrik Di Distrik Dili Timor-Leste, tentang perlakuan terhadap sesama warga negara secara (Diskriminasi) karena kesejahteraan rakyat harus menjadi hukum tertinggi dalam suatu negara "salus publica suprema lex". Penelitian ini merupakan penelitianhukum yuridis Empirik. Sifat penelitian ini adalah deskriptif yang mempergunakan data primer dan data sekunder. Hasil penelitian menunjukkan bahwa Setiap pelayanan yang diberikan pemerintah melalui Electricidade de Timor Leste(EDTL) sebagai penyalur energi kelistrikan mulai dari pembangkitan transmisi dan distribusi energi listrik yang menjadi sumber pasokan ke seluruh masyarakat yang menyebar luas di Distrik Dili Timor Leste pada kenyataannya menyimpang dari amanat konstitusi yang ada untuk kesejahteraan rakyat. Penyimpangan yang terjadi ditindaklanjuti dengan tindakan hukum yang tidak adil terhadap berbagai tingkatan/golongan yang ada dalam masyarakat sebagai pelanggan. Ketidakadilan dalam penanganan yang semestinya pada dasarnya terjadi karena adanya intervensi kekuasaan, baik ekonomi maupun politik.

\section{Kata Kunci: Diskriminasi, Penegakan Hukum, Pencurian Listrik}

1 Program Studi Ilmu Hukum Program Pascasarjana Universitas Nusa Cendana, email nonu.fatima@ yahoo.com

2 Fakultas Hukum Universitas Nusa Cendana, Kupang

3 Fakultas Hukum Universitas Nusa Cendana, Kupang
\end{abstract}




\section{PENDAHULUAN}

Realitas menunjukkan bahwa tatanan hukum akan berfungsi dengan baik dalam sebuah negara,pada umumnya tercermin dari sikap, perilaku, tindakan bahkan keputusan politik atau putusan hukum dari penyelenggara negara (penguasa) yang senantiasa berpihak pada keadilan masyarakat banyak di negara yang bersangkutan. Hukum di negara tersebut ditegakkan secara obyektif dan konsisten tanpa diskriminasi baik dalam penyelenggara negara atau pemerintahan serta warga negaranya, yang seharusnya patuh pada hukum.

Prinsip hukum Timor-Leste adalah negara tunduk pada UndangUndang Dasar (UUD) dan hukum. (Estadu hakruuk ba Lei-Inan no lei-oan sira). Hal ini sebagaimana ditegaskan dalam ketentuanPasal 2 ayat (2) Konstitusi Republik Demokratis Timor-Leste. Prinsip kehidupan bermasyarakat, berbangsa dan bernegara yang demikian akan menciptakan komunikasi dan interaksi sosial antara berbagai elemen komunitas, sehingga dapat berlangsung dengan baik untuk mencapai tujuan dan cita-cita bersama. Hal ini berarti bahwa tatanan kehidupan dan komunikasi antar individu dalam suatu komunitas dituntut mengacu kepada aturan yang disepakati, dan dipakai sebagai acuan atau referensi para pihak dalam melakukan hubungan sosial. Kehadiran norma hukum sebagai acuan dalam kehidupan bersama tersebut merupakan konsekuensi logis dari adagium yang dikemukakan oleh Marcus Tullius Cicero, yaitu $u b i$ sucietas ibi ius.(dimana ada masyarakat di situ ada hukum) $)^{4}$.

Konstitusi sebagai hukum dasar atau sebagai hukum tertinggi (Supremy of Law in the state), secara hirarkis dijabarkan lebih lanjut dalam berbagai undang-undang untuk mengatur segala aktifitas masyarakat, sesuai dengan prosedur yang ditetapkan oleh negara melalui pemerintah. Harapan yang tertuang didalam konstitusi maupun didalam produk hukum turunannya dalam keyataan belum secara efektif dilaksanakan oleh para elemen negara. Bahkan, dalam praktekpelaksanaannya tidak jarang menunjukan praktekpraktek diskriminatif, padahal di dalam negara hukum terdapat pendirian bahwa semua orang dipandang sama di hadapan hukum (equaliti before the law). Hal yang sama juga dipertegas oleh Elisabeth Nurhaini Butarbutar ${ }^{5}$ bahwa Semua manusia dipandang sama sehingga harus diperlakukan sama (asas equaliti before the law). Oleh sebab itu Jika terjadi tindakan diskriminatif dalam penegakan hukum maka jelas akan menimbulkan problem ketidakadilan dalam kehidupan negara hukum. Hal ini dikarenakan masih

4 Satjipto Rahardjo, 2008, Biarkan Hukum Mengalir Catataan Kritis Tentang Pergulatan Manusia dan Hukum, Jakarta, Kompas, hlm 9

5 Elisabeth Nurhaini Butarbutar, KONSEP KEADILAN DALAM SISTEM PERADILAN PERDATA, Jurnal Mimbar Hukum, Volume 21, Nomor 2 Juni 2009, hlm 2 
banyak pihak yang berusaha untuk mempertahankan kekuasaan dan memperjuangkan kepentingannya sendiri atau kelompok, sementara kepentingan masyarakat pada semua lapisan masih terabaikan.

Permasalahan yang bertentangan dengan ketentuan Konstitusi adalah diskriminasi penanganan kasus pencurian arus listrik, terutama di Distrik Dili Negara RDTL, yang terindikasi adanya perlakuan diskriminatif. Realitas yang demikian itu sesungguhnya bertentangan dengan Konstitusi Timor Leste terutama pasal 16 ayat (1) dan (2)yang secara tegas mengamanatkan tentang asas atau prisip Universalitas dan persamaan (Universalidade no igualdade). Ketentuan Pasal 16 ayat (1) dan (2) tersebut sebagai berikut:

1. Semua warga negara adalah sama di depan hukum, memiliki hak yang sama dan tunduk pada kewajiban yang sama.

2. Tidak seorangpun dapat mengalami diskriminasi berdasarkan alasan warna kulit, ras, status perkawinan, jenis kelamin, asal etnis,bahasa, kedudukan sosial atau ekonomi, keyakinan politik atau ideologi, agama, pendidikan, keadaan jasmani atau mental.

Khusus di Distrik Dili, hingga saat ini Electricidade de Timor Leste (EDTL) sudah banyak melayani pelanggan yang tersebar di lima kecamatan, yaitu Kecamatan Vera-
Crus, Nain-Feto, Kristo-Rei, Dom Alexo, dan Kecamatan Atauro. Perkembangan pelanggan di lima kecamatan Distrik Dili tersebut terus berkembang dari tahun ke tahun. Berikutinidigambarkan data pelanggan EDTL di Di Distrik Dili hingga tahun 2016 dengan total 49.548 pelanggan dari sekian banyak pelanggan yang terdapat di Distrik Dili khususnya Ibu Kota Negara Timor Leste.

Hasil temuan tim gabungan operasi listrik Electricidade De TimorLeste(EDTL) atau PLN (Perusahaan Listrik Negara) menunjukan bahwa banyak pelanggan yang melakukan pencurian arus listrik termasuk juga pegawai pemerintahan dan pejabat negara yang berada di Distrik Dili. Untuk menindaklanjuti penanganan kasus pencurian arus listrik tersebut justru dilakukan secara tidak merata, terhadap sebagian pelangan di nilai terjadinya diskriminatif. Perlakukan yang diskriminatif menyebabkan adanya ketidakadilan bagi semua padahal kita tahu bahwa perlakuan yang adil adalah kebutuhan mendasar bagi masyarakat seperti yang dikatakan oleh Sri Yuliani ${ }^{6}$ dalam jurnal nya bahwa Kebutuhan akan perlakuan yang adil dalam hidup bernegara dan bermasyarakat menjadi kebutuhan asasi setiap manusia. Perlakuan yang tidak sama sesungguhnya megingkari

6 Sri Yuliani, MENGUAK KONSTRUKSI SOSIAL DIBALIK DISKRIMINASI TERHADAP WARIA, Jurnal Sosilogi Dilema, ISSN : 0215 - 9635, Vol. 18 No. 2 Th. 2006, hlm 1 
asas persamaan di hadapan hukum. Selain mengingkari asas persamaan di depan hukum perbuatan pencurian arus listrik, melanggar ketentuanketentuan yang ada pada Kitab Undang-undang Hukum Pidana Timor Leste dan Undang-undang Nomor 13 Tahun 2003 tentang Penggunaan Daya Listrik.

Hal tersebut yang mendorong penulis untuk melakukan penelitian secara lebih mendalam untuk memberikan solusi terhadap penanggulangan pencurian arus listrik yang juga dilakukan oleh para pejabat atau pegawai negara yang mendapat gaji dan fasilitas negara, maupun kaum kapitalis yang memiliki kekuatan ekonomi yang besar. Perbuatan tersebut jika tidak ditangani secara baik, maka akan mencederai hukum dan nilai-nilai keadilan.Problem research yang muncul dari uraian di atas adalah bahwa adanya perlakuan yang tidak sama atau diskriminatif dalam penanganan kasus pencurian arus listrik di Distrik Dili yang dilakukan oleh masyarakat biasa, para pejabat yang memiliki kekuatan kekuasaan dan kaum kapitalis yang memiliki kekuataan ekonomi. Dinamika bekerjanya hukum sangat ditentukan oleh kekuatan nonhukum, dalam hal ini kekuatan personal dan sosial. Perlakuan yang diskriminatif tersebut menjadikan persoalan pencurian arus listrik yang terjadi di Distrik Dili yang merupakan Ibu Kota Negara Timor Leste menjadi persoalan hukum yang urgen untuk dikaji dalam suatu karya ilmiah. Merujuk pada uraian latar belakang di atas maka permasalahan yang dikaji dalam penulisan ini yaitu : 1. Mengapa Terjadinya Diskriminasi Dalam Penanganan Tindak Pidana Pencurian Arus Listrik di Timor Leste?

2. Apa Sajakah Faktor-Faktor Non Hukum Yang Mempengaruhi Proses Penegakan Hukum Terhadap Penanganan Tindak Pidana Pencurian Arus Listrik di Distrik Dili Timor Leste ?

Jurnal ini merupakan hasil karya dari penulis sendiri dan berdasarkan hasil penelusuran terhadap artikel dan jurnal ilmiah di website tidak ditemukan jurnal atau artikel yang serupa dengan persoalan yang ditulis. Namun untuk persoalan kekerasan dalam rumah tangga bukan merupakan fenomena yang baru hal ini dibuktikan dengan adanya beberapa jurnal yang menulis tentang persoalan kekerasan dalam rumah tangga yaitu :

1. Devilla Sari, Utomo Sarjono Putro, Yos Sunitiyoso, Pri Henmawan, Dhanan Sarwo Utomo, kelompok keahlian pengambilan keputusan dan negosiasi strategis sekolah bisnis dan manajemen-institut teknologi bandung, Jurnal Menejemen Teknologi, Aplikasi Norm Game dan Locus Of Control Untuk Pengembangan Kebijakan Penanggulangan Pencurian Listri, Volume 9 No.1 
Edisi 2010 Institut Teknologi Bandung.

2. Khalif ahadi dan M. Indra Al Irsyad, Pusat Penelitian Dan Pengembangan Teknologi Ketenagalistrikan, Energy Baru Terbarukan Dan Konservasi Energy. Jurnal topic hukum, Strategi Efisiensi Pembiayaan Pemerintah Untuk Memacu Pelaksanaan Konservasi Energy Pada Sector Ketenagalistrikan,

Tujuan Penelitian ini adalah Untuk mengetahui dan menganalisis terjadinya Diskriminasi Dalam Penanganan Tindak Pidana Pencurian Arus Listrik di Timor Leste dan Untuk mengetahui dan menganalisis faktor-faktor Non Hukum Yang Mempengaruhi Proses Penegakan Hukum Terhadap Penanganan Tindak Pidana Pencurian Arus Listrik di Distrik Dili Timor Leste

\section{METODE PENELITIAN}

Mengacu pada tema dan permasalahan yang diangkat dalam penelitian ini, maka peneliti menggunakan penelitian hukum yuridis Empirik. Dalam hal ini adalah penelitian mengenai Diskriminasi Penegakan Hukum Dalam Penaganan Kasus Pencurian Arus Listrik Di Distrik Dili. Sifat penelitian ini adalah deskriptif yang mempergunakan data primer dan data sekunder. Data primer diperoleh langsung dari informan. Para informan tersebut antara lain: para pelanggan Electricidade De TimorLeste (EDTL) dan para pegawai atau staf lapangan serta kepala bagian yang bekerja di kantor pusat Electricidade De Timor-Leste(EDTL) Distrik Dili Timor Leste. Data sekunder diperoleh dari buku, karya ilmiah, dan peraturan perundang-undangan yang berkaitan dengan penelitian. Penelitian lebih melihat pada dugaan-dugaan dan pernyataan-pernyataan mengenai prilaku hukum yang ada dalam masyarakat yang merupakan fakta sosial.Yang dimaksud dengan fakta sosial adalah apa yang dirasakan oleh sebagian besar anggota masyarakat sebagai masalah, dalam hal ini yang dimaksud tentulah masalah yang meyangkut dengan prilaku hukum. ${ }^{7}$

\section{HASIL DAN PEMBAHASAN 3.1 Diskriminasi Dalam Penanganan Tindak Pidana Pencurian Arus Listrik Di Timor Leste}

Persamaan di hadapan hukum yang diartikan secara dinamis ini dipercayai akan memberikan jaminan adanya akses untuk memperoleh keadilan (access to justice) oleh karena itu dalam rangka tegaknya supermasi hukum,suatu hukum yang adil seharusnya sesuai dengan konstitusi yang benar, dan jika menyimpang dari konstitusi pasti tidak adil. Namun perlu kita ketahui juga bahwa untuk mendefinisikan kata adil sangatlah sulit karena adil mempunyai makna yang berdimensi luas sehingga ketika adil menurut sekelompok orang belum

7 Bahder Johan Nasution, 2008 Metode Penelitian Hukum, Mandar Maju Bandung, hlm. 162 
tentu adil menurut sebagian orang lainnya seperti yang dikatakan oleh Inge Dwisvimiar ${ }^{8}$ dalam jurnal nya bahwa ukuran mengenai keadilan seringkali ditafsirkan berbedabeda artinya keadilan itu sendiri berdimensi banyak dalam segala bidang. Pelaksanaan hukum di dalam masyarakat selain tergantung pada kesadaran hukum masyarakat juga sangat banyak ditentukan oleh aparat penegak hukum, oleh karena sering terjadi beberapa peraturan hukum tidak dapat terlaksana dengan baik oleh karena ada beberapa oknum penegak hukum yang tidak melaksanakan suatu ketentuan hukum sebagai mana mestinya ${ }^{9}$.

Kebebasan dalam organisasi politik, merupakan konsekuensi logis oleh hukum atau konstitusi atas hakhak dasar dan hak asasi manusia dalam kehidupan kenegaraan. Kebebasan mengeluarkan pendapat dan pikiran merupakan indikasi bahwa suatu Negara melaksanakan demokrasi setiap Negara hukum yang demokrasi harus memasukan aspek peran serta aktif rakyat di dalam konstitusi nya yang dilandasi persamaan dan kemerdekaan atau kebebasan ${ }^{10}$. Sebagai negara hukum (rechtsstaat) sebagaimana

8 Inge Dwisvimiar, KEADILAN DALAM PERSPEKTIF FILSAFAT ILMU, Jurnal Dinamika Hukum, Vol.2 No. 3 September 2011, hlm. 1

9 Sanyoto, PENEGAKAN HUKUM DI INDONESIA, Jumal Dinamika Hukum, Vol.8 No.3 Edisi September 2008, hlm. 200

10 Sri Hartini, PENEGAKAN HUKUM NETRALITAS PEGAWI NEGERI SIPIL PNS, Jurnal Dinamika Hukum, Vol. 9 No. 3 Edisi September 2009, hlm. 260. ditegaskan dalam ketentuan Pasal 2 ayat (2) Undang-Undang Dasar Negara Republik Demokrat Timor Leste yang menyatakan Negara tunduk pada Undang-Undang Dasar (UUD) dan hukum. Maka negara harus menjamin persamaan setiap orang di hadapan hukum serta melindungi hak asasi manusia. Persamaan di hadapan hukum memiliki arti bahwa semua orang memiliki hak untuk diperlakukan sama di hadapan hukum (Equality Before The Law). Persamaan perlakuan di hadapan hukum bagi setiap orang berlaku dengan tidak membedabedakan latar belakang antara lain: ras, agama, keturunan, pendidikan atau tempat lahirnya.Sebagaimana sudah ditetapkan oleh Konstitusi Timor Leste terutama pada pasal 16 ayat (1) dan (2)yang secara tegas mengamanatkan tentang asas atau prisip Universalitas dan persamaan (Universalidade no igualdade).

hasil penelitian yang ditemukan bahwa pemerintah sendiri sudah melakukan tindakan diskriminasi terhadap sesama masyarakat, beberapa hasil penelitian tentang maraknya pencurian arus listrik yang terjadi di Distrik Dili dari tahun 2015 menunjukkan bahwa pelanggan Electricidade De Timor-Leste (EDTL) yang melakukan pencurian sebanyak 1,230 dan tahun 2016 sebanyak 2,085. dari jumlah keseluruhan pada dua tahun terakhir ini mencapai 3,315 yang mendapatkan sanksi pemutusan aliran. Dari hasil rekapitulasi dari semua pelanggan yang menggunakan pripago di Distrik Dili Timor Leste dengan 
total 31.230 Pripago yang digunakan oleh para pelanggan Electricidade De Timor-Leste (EDTL). Dari banyaknya pelanggan secara keseluruhan dari tahun 2015 sampai dengan 2016 yang melakukan tindakan pencurian arus listrik tersebut, menunjukan bahwa kurangnya perhatian dari pihak pemerintah melalui kementrian perindustrian dan telekomunikasi yang ada dibawah pengontrolan Electrisidade de Timor Leste (EDTL), sehingga menyebabkan terjadinya kerugian negara yang sangat banyak.

Fakta menunjukkan bahwa sampai sekarang masih banyak para pelanggan yang tidak diperhatikan oleh pemerintah, atau penggunaan aliran listrik mereka tidak dibawah pengontrolan Electrisidade de Timor Leste (EDTL), sehingga mereka masih bebas dari beban dibandingkan dengan masyarakat yang sudah menjadi pelanggan tetap oleh EDTL. Seperti masyarakat yang berada pada kecamatan Krito Rei, Desa Here dengan jumlah penduduk yang begitu banyak, yang terdiri dari 700 kk, yang berada di Desa Hera dengan klasifikasi penduduk yang beragam antara lain rakyat biasa, veteran, para pejabat pemerintahan dan juga orangorang yang berkelas komersial. Hal ini menunjukkan bahwa pemerintah hanya bisa memperhatikan pada segelintir masyarakat dan tidak secara keseluruhan, seperti masyarakat yang berada di Kecamatan Krito-Rei Desa Hera tersebut, yang sampai sekarang mereka bebas menggunakan meteran lama yang merupakan peninggalan Indonesiapada saat Timor-Timormasih dibawah jajahan. Berdasarkan fakta yang dijelaskan diatas, terlihat jelas sekali bahwa terjadinya Diskriminasi yang dilakukan oleh pemerintah terhadap masyarakat, khususnya pada Distrik Dili Timor-Leste.

Masalah penegakan hukum merupakan masalah yang tidak sederhana, bukan saja karena kompleksitas sistem hukum itu sendiri, tetapi juga jalinan hubungan antara sistem hukum dengan sistem sosial, politik, ekonomi, dan budaya masyarakat. Sebagai suatu proses, penegakan hukum pada hakikatnya merupakan variabel yang mempunyai korelasi dan interpendensi dengan factor-faktor lain, sebagaimana diungkapkan oleh Lawrence M Friedman, yaitu komponen substansi, struktur dan kultur. Komponen tersebut termasuk ruang lingkup bekerjanya hukum sebagai suatu sistem. Ke semua factor tersebut akan sangat menentukan proses penegakan hukum dalam masyarakat dan tidak dapat dipisahkan satu dengan lainnya. Kegagalan pada salah satu komponen akan berimbas pada faktor yang lainnya ${ }^{11}$.

Penegakan hukum merupakan suatu proses untuk mewujudkan keinginan-keinginan hukum menjadi kenyataan. Keinginan-keinginan hukum yang dimaksud di sini

11 Kartono, PENEGAKAN HUKUM LINGKUNGAN ADMINISTRATIF DALAM UNDANG-UNDANG PERLINDUNGAN DAN PENGELOLAAN LINGKUNGAN HIDUP, Jurnal Dinamika Hukum, Vol.9 No. 3 Edisi September 2009, hlm. 250 
merupakan pikiran-pikiran badan pembentuk undang-undang yang dirumuskan dalam peraturan-peraturan hukum. ${ }^{12}$ Sebagai Negara hukum yang baik maka Menurut Satjipto,Negara Hukum Yang Membahagiakan Rakyat juga cenderung untuk menjadi negara hukum yang progresif, bila dilihat dari inisiatif yang selalu datang dari pihak negara. Untuk meujudkan negara tersebut, maka negara akan selalu aktif mengambil inisiatif untuk bertindak. Bukan rakyat yang harus "memintaminta" untuk dilayani oleh negara, melainkan negaralah yang aktif datang kepada rakyat ${ }^{13}$.

3.2 Faktor-Faktor Non Hukum Yang Mempengaruhi Proses Penegakan Hukum Terhadap Penanganan Tindak Pidana Pencurian Arus Listrik Di Distrik Dili Timor Leste

Dengan perkembangan hukum yang dipengaruhi oleh kekuatan politik menyebabkan pemerintahan yang sedang berkuasa akan menjadi represif dan tidak lagi memperhatikan kepentingan orangorang di sekitarnya. Berkembangnya kekuasaan politik menyebabkan

12 Suwari Akhmaddhian, PENEGAKAN HUKUM LINGKUNGAN DAN PENGARUHNYA TERHADAP PERTUMBUHAN EKONOMI DI INDONESIA (STUDI KEBAKARAN HUTAN TAHUN 2015), Jurnal Unifikasi, ISSN 2354-5976, Vol.03 No 01, Edisi Januari 2016, hlm. 6.

13 Satjipto Rahardjo, 2009, Negara Hukum Yang Membahagiakan Rakyat, Yogyakarta, Penerbit Genta Publishing, hlm.106. kekuasaan kehakiman menjadi kotor karena adanya pemufakatan jahat yang dibuat berdasarkan kesepakatan oleh sekelompok orang untuk mencapai tujuan-tujuannya yang mengatasnamakan kepentingan masyarakat untuk menciptakan perdamaian dan kesejahteraan masyarakat.Pada dasarnya kekuasaan politik itu merupakan kekuasaan yang sangat sulit untuk dikalahkan, dan kekuasaan adalah "Kemampuan seseorang atau kelompok untuk mempengaruhi tingkah laku orang atau kelompok lain sesuai dengan keinginan pelaku.

Problem lain yang menyebabkan lemahnya penegakan hukum adalah tindakan diskriminatif terhadap penanganan tindak pidana pencurian arus listrik secara ilegal,sehingga mendapatkan perlakuan dan sanksi yang berbeda, bagi para pelanggan Electrisidade de Timor Leste (EDTL) yang mempunyai status sosial yang tinggi di tengah-tengah masyarakat akan diperlakukan secara istimewa, sedangkan pelanggan Electrisidade de Timor Leste (EDTL) yang mempunyai status sosial lebih rendah diperlakukan semestinya sesuai dengan prosedur yang ditetapkan untuk semua pelanggan.

Penegakan hukum seolah hanya berpihak pada pelanggan Electrisidade de Timor Leste (EDTL) yang mempunyai status sosial yang tinggi, tetapi tidak pada pelanggan Electrisidade de Timor Leste (EDTL) 
yang mempunyai status sosial lebih rendah. Bahkan hukum berpihak pada mereka yang memiliki jabatan dan koneksi dengan para pejabat hukum atau mudah untuk lebih cepat mendapatkan proses pelayanan dari pada penegakan hukum demi tercapainya suatu keadilan, dan menjadikan tembok penghalang bagi rakyat untuk memperoleh keadilan yang lebih benar. Ini semua karena mentalitas aparat penegakan hukum yang lebih melihat kedudukan seseorang di masyarakat atau status sosialnya dari apa yang diperbuat oleh orang yang menghadapi proses hukum. Belum lagi dalam mentalitas aparat penegak hukum terdapat perasaan rendah diri terhadap mereka yang memiliki pangkat dan jabatan yang bisa dianggap sebagai sosok yang memiliki status sosial lebih tinggi, dan Status sosial seolah menjadi penting bagi mereka yang menghadapi proses hukum. Semakin tinggi status sosial, semakin tinggi rasa sungkan dari aparat penegak hukum.

Dari hasil wawacara yang dilakukan oleh peneliti terhadap kepala departemen pelayanan, Zenilo A. Smith, di kantor pusat EDTL,tentang para pelanggan EDTL atau konsumen yang berada di distrik Dili, diketahui bahwa banyak hal yang mereka hadapi terlebih para pelanggan melanggar aturan dan melakukan tindakan main hakim sendiri, baik yang dilakukan oleh masyarakat biasa, pejabat negara, para usahawan maupun kaum kapitalis yang memiliki kekuatan ekonomi yang besar.Darisekianbanyakpermasalahan ini terindikasi adanya pelayanan yang tidak merata dari EDTL terhadap para pelanggan, yang disebabkan oleh banyak faktor penghambat dalam pelayanan sehingga proses sanksi administrasi tidak berjalan dengan baik.Sanksi lain yang diberikan adalah tindakan pemutusan aliran listrik, namun tindakan pemutusan aliran listrikdinilai sangat diskriminatif, karna di pengaruhi oleh kekuatan kekuasaan, politik, dan ekonomi sehingga proses tidak berjalan dengan baik. ${ }^{14}$

Dominasi politik terhadap perumusan produk hukum sehingga tidak lagi seimbang antara hukum dan politik syarat dengan politik kepentingan dalam perumusannya sehingga kualitas yang di hasilkan tidak menyentuh bahkan tidak menjawab persoalan yang timbul dalam masyarakat karena tujuan dibuatnya produk hukum untuk kepentingan yang berkepentingan. ${ }^{15}$ Dari keadaan hegemonial yang demikian ini menyebabkan hukum menjadi kehilangan otonomi, otentisitas dan profesionalisme dalam bekerjanya. Hukum menjadi terkooptasi oleh

14 Hasil wawancara dengan kepala departemen pelayanan terhadap para pelangang EDTL atau konsumen (Chefe Dep.Dez.Cliente) Zenilo A. Smith, Pada Tanggal 8 Februari 2017 di kantor pusat Electricidade de Timor Leste (EDTL) Distrik Dili Timor Leste

15 Abdus Salam, PENGARUH POLITIK DALAM PEMBENTUKAN HUKUM DI INDONESIA, Jurnal Pemikiran Hukum Islam, Vol.XIV No 2 Edisi Desember 2015 , hlm 124 . 
kekuasaan, dan tidak mampu bekerja untuk menyelesaikan pekerjaanya dengan benar.Kekuasaan politik yang telah memasuki bidang ekonomi memberikan andil dan pengaruhnya yang sangat penting dalam produk hukum.Dari pemikiran yang dijelaskan oleh Seidman di atas menjelaskan bahwa dinamika berjalanya hukum sangat dipengaruhi oleh struktur kekuasan yang sering mengintervensi terhadap proses jalan-nya hukum, maka para penegak hukum di negara ini merasa bahwa mereka tidak mempunyai kekuasaan independen terhadap terselengaranya hukum di negara tersebut.Hukum tidak berjalan dengan baik sesuai dengan amanat Konstitusi dan kemauan rakyat yang selama ini merindukan adanya keadilan sosial berdasarkan prosedural, bahwa semua proses harus sesuai dengan aturan main hukum yang ditetapkan oleh negara melalui undang-undang yang ada.

\section{KESIMPULAN}

1. Negara menghindari perbedaan perlakuan terhadap sesama warga negara (Diskriminasi) dengan menjadikan hukum sebagai panglima tertinggi dalam suatu pemerintahan, sehingga kesejahteraan rakyat harus menjadi hukum tertinggi dalam suatu negara "salus publica suprema lex". Setiap pelayanan yang diberikan pemerintah melalui Electricidade de Timor
Leste(EDTL) sebagai penyalur energi kelistrikan yang menyebar luas di Distrik Dili ibu kota negara Timor Leste pada kenyataannya menyimpang dari amanat konstitusi. Ketidakadilan dalam penanganan yang semestinya pada dasarnya terjadi karena adanya intervensi kekuasaan, baik ekonomi maupun politik.

2. Faktor yang menyebabkan sulitnya penegakan hukum di Timor Leste, yakni di antaranya, Berbagai undang-undang yang dibuat yang notabene-nya adalah representatif dari hukum hanya mengutamakan kepentingan penguasa. Para pemegang kekuasaan sering mengintervensi proses jalannya penegakan hukum yang sedang berjalan, sehingga para penegakan hukum sulit sekali untuk menegakkan hukum yang sesuai dengan koridor hukum yang ada.

\section{DAFTAR PUSTAKA}

Bahder Johan Nasution, 2008, Metode Penelitian Hukum, Mandar Maju, Bandung

Satjipto Rahardjo, 2008, Biarkan Hukum Mengalir, Catataan Kritis Tentang Pergulatan Manusia dan Hukum, Kompas, Jakarta 2009, Negara

Hukum Yang Membahagiakan Rakyat, Genta Publishing, Yogyakarta

Abdus Salam, Pengaruh Politik 
Dalam Pembentukan Hukum

Di Indonesia, Jurnal Pemikiran

Hukum Islam, Vol.XIV No 2

Edisi Desember 2015

Elisabeth Nurhaini Butarbutar,

Konsep Keadilan Dalam Sistem

Peradilan Perdata, Jurnal

Mimbar Hukum, Volume 21,

Nomor 2 Juni 2009

Inge Dwisvimiar, Keadilan Dalam

Perspektif Filsafat Ilmu, Jurnal

Dinamika Hukum, Vol. No. 3

September 2011

Kartono, Penegakan Hukum

Lingkungan AdministratifDalam

Undang-undang Perlindungan dan Pengelolaan Lingkungan Hidup, Jurnal Dinamika Hukum, Vol.9 No. 3 Edisi September 2009

Sanyoto, Penegakan Hukum Di

Indonesia, Junal Dinamika Hukum, Vol.8 No.3 Edisi September 2008

Sri Yuliani, MenguakKonstruksi Sosial Dibalik Diskriminasi Terhadap Waria, Jurnal Sosilogi Dilema, ISSN : 0215 - 9635, Vol. 18 No.

2 Tahun 2006

Sri Hartini, Penegakan Hukum Netralitas Pegawi Negeri Sipil PNS, Jurnal Dinamika Hukum, Vol. 9 No. 3 Edisi September 2009

Suwari Akhmaddhian, Penegakan Hukum Lingkungan dan Pengaruhnya Terhadap Pertumbuhan Ekonomi Di Indonesia (Studi Kebakaran
Hutan Tahun 2015), Jurnal Unifikasi, ISSN 2354-5976, Vol.03 No 01, Edisi Januari 2016. 